University of Texas Rio Grande Valley

ScholarWorks @ UTRGV

$3-1-2018$

\title{
Winter Site Fidelity of Orange-Crowned Warblers (Oreothlypis celata) in the Lower Rio Grande Valley of Texas
}

Mark H. Conway

Timothy Brush

The University of Texas Rio Grande Valley

Follow this and additional works at: https://scholarworks.utrgv.edu/bio_fac

Part of the Biology Commons, and the Ornithology Commons

\section{Recommended Citation}

Mark H. Conway and Timothy Brush "Winter Site Fidelity of Orange-Crowned Warblers (Oreothlypis celata) in the Lower Rio Grande Valley of Texas," The Southwestern Naturalist 63(1), 87-89, (1 March 2018). https://doi.org/10.1894/0038-4909.63.87

This Article is brought to you for free and open access by the College of Sciences at ScholarWorks @ UTRGV. It has been accepted for inclusion in Biology Faculty Publications and Presentations by an authorized administrator of ScholarWorks@ UTRGV. For more information, please contact justin.white@utrgv.edu,william.flores01@utrgv.edu. 
Winter Site Fidelity of Orange-Crowned Warblers (Oreothlypis celata) in the Lower Rio Grande Valley of Texas

Authors: Conway, Mark H., and Brush, Timothy

Source: The Southwestern Naturalist, 63(1) : 87-89

Published By: Southwestern Association of Naturalists

URL: https://doi.org/10.1894/0038-4909.63.87

BioOne Complete (complete.BioOne.org) is a full-text database of 200 subscribed and open-access titles in the biological, ecological, and environmental sciences published by nonprofit societies, associations, museums, institutions, and presses.

Your use of this PDF, the BioOne Complete website, and all posted and associated content indicates your acceptance of BioOne's Terms of Use, available at www.bioone.org/terms-of-use.

Usage of BioOne Complete content is strictly limited to personal, educational, and non - commercial use. Commercial inquiries or rights and permissions requests should be directed to the individual publisher as copyright holder.

BioOne sees sustainable scholarly publishing as an inherently collaborative enterprise connecting authors, nonprofit publishers, academic institutions, research libraries, and research funders in the common goal of maximizing access to critical research. 
The Southwestern Naturalist 63(1): 87-89

\title{
WINTER SITE FIDELITY OF ORANGE-CROWNED WARBLERS (OREOTHLYPIS CELATA) IN THE LOWER RIO GRANDE VALLEY OF TEXAS
}

\author{
Mark H. Conway and Timothy Brush* \\ Lower Rio Grande Valley Avian Research, 2106 Emerald Lake Drive, Harlingen, TX 78550 (MHC) \\ Department of Biology, University of Texas Rio Grande Valley, 1201 West University Drive, Edinburg, TX 78539 (TB) \\ *Correspondent: timothy.brush@utrgv.edu
}

ABSTRACT-We documented between-winter site fidelity of orange-crowned warblers (Oreothlypis celata) in the Lower Rio Grande Valley of Texas, between 2004 and 2017. Overall, we recaptured $13.9 \%$ of the 201 banded birds in $\geq 1$ subsequent winter season: $20.8 \%$ of the 101 birds banded in urban natural areas, and $7.0 \%$ of the 100 banded in rural areas. We recaptured 8 birds $\geq 3$ winters after their initial capture, indicating extended winter site fidelity.

RESUMEN-Documentamos la fidelidad al sitio invernal de los chipes oliváceos (Oreothlypis celata) en el Valle del Río Grande Baja de Texas entre 2004 y 2017. En general, se recapturó el 13.9\% de los 201 individuos anillados en al menos una temporada invernal posterior: el 20.8\% de los 101 individuos anillados en las áreas urbanas naturales, y el $7.0 \%$ de los 100 anillados en el área rural natural. Recapturamos 8 aves tres o más inviernos después de su captura inicial, lo que indica la fidelidad prolongada al sitio invernal. 
The orange-crowned warbler (Oreothlypis celata) is a 9-10g, insectivorous North American warbler (family Parulidae) commonly wintering across the southernmost United States and much of Mexico, well north of the winter range of most warblers. Many orange-crowned warblers winter in areas that regularly have low temperatures $<10^{\circ} \mathrm{C}$ (Gilbert et al., 2010). Site fidelity, in which birds remain on a site throughout the winter or return to wintering locations in subsequent winters, may increase winter survival because of the birds' greater familiarity with local conditions. Ruiz-Gutierrez et al. (2016) estimated an average winter residency of 3.7 months by orange-crowned warblers at Mexican and Central American wintering sites, but there is little information on winter site fidelity (Somershoe et al., 2009).

The Lower Rio Grande Valley of Texas (Starr, Hidalgo, Cameron, and Willacy counties) has a subtropical climate with infrequent winter freezes, and many evergreen woody plants suitable for foliage-searching orangecrowned warblers (Rosenberg et al., 1991). The species occurs commonly during October-April in this region (Arvin, 2005; Lockwood and Freeman, 2014). Orangecrowned warblers occur in native thornscrub, thornforest, and taller riparian forest, as well as smaller urban natural areas. We predicted that we would see betweenwinter site fidelity. Urban natural areas may have more structurally diverse natural vegetation and consistently available water sources; therefore, we predicted greater site fidelity there compared with natural areas located in rural areas.

All study areas were subtropical thorn-forest (Brush, 2005) in Cameron or Hidalgo counties, $<50 \mathrm{~m}$ above sea level. Our rural study area was within the 310-ha Arroyo Colorado unit of Las Palomas Wildlife Management Area, near Harlingen, Cameron County. We had two urban sites in southern Hidalgo County, both mixed thorn-forest and thornscrub with small openings: Quinta Mazatlan, a 16-ha park in McAllen, Texas, and Valley Nature Center, a 2.4-ha park in Weslaco, Texas. Park staff maintained feeding stations on a very irregular basis in both these areas, and we observed orange-crowned warblers feeding from oranges, when available.

We conducted banding of orange-crowned warblers as part of regular banding for a variety of species (M.H.C. performed all the banding; USFWS permit \#22758). We typically used $30-\mathrm{mm}$ mesh nets, opened at daylight for approximately $5 \mathrm{~h}$ during the October-April nonbreeding season, 2004-2017 (we banded at Arroyo Colorado from 2004 to 2017, at Valley Nature Center from 2006 to 2017, and at Quinta Mazatlan from 2008 to 2017). Banding was much more frequent at the rural sites than at urban sites.

Overall, we recaptured 36 individuals $(17.9 \%)$ of the 201 orange-crowned warblers that we banded, including birds recaptured in the same winter and in subsequent winters. Of the 101 birds banded at urban sites, we recaptured $26.7 \%$ at least once, showing greater overall winter site fidelity than the $9.0 \%$ (of 100 banded birds) recaptured at rural sites $\left(\chi^{2}=10.74, P<0.01\right)$.

Looking only at birds showing between-winter site fidelity, we recaptured $13.9 \%$ of the 201 banded birds in $\geq 1$ subsequent winter (Table 1 ). Of the 101 birds banded at urban sites, we recaptured $20.8 \%$ in $\geq 1$ subsequent winter, which was greater than $7.0 \%$ of the 100 birds at the rural site $\left(\chi^{2}=6.50, P<0.05\right)$. Overall, we recaptured $28.6 \%$ of the 28 birds showing between-winter site fidelity $\geq 3$ winters after we banded them, indicating extended site fidelity. We recaptured two of those birds in winters $\geq 5$ years after they were banded, both in the urban Quinta Mazatlan site. We banded one in 2009-2010 and recaptured it in 2016-2017. We banded the other in 2010-2011 and recaptured it in 2015-2016 and 20162017.

This is the first study to show regular between-winter site fidelity in orange-crowned warblers, especially in urban sites. Birds recaptured 3-7 winters after their original capture showed extended between-winter site fidelity. In the only other multiyear study, a 5-year, intensive banding study of nonbreeding site fidelity in central Florida, $15.4 \%$ (2 individuals) of the 13 orangecrowned warblers banded in winter were recaptured in the following winter season (Somershoe et al., 2009). Our urban winter site fidelity of $20.3 \%$ is greater than the $10.4 \%$ site fidelity for closely related Nashville warblers (O. ruficapilla) in urban southern Mexico (Monroy-Ojeda et al., 2013). Urban natural areas may be more attractive than rural natural areas to orange-crowned warblers because such areas are managed somewhat for biodiversity and often have feeding stations. The actual winter site fidelity in both urban and rural sites in the Lower Rio Grande Valley of Texas may be greater than we found and deserves further study.

TABLE 1-Banding frequency and number of orange-crowned warblers banded and recaptured in urban and rural study sites in the Lower Rio Grande Valley of Texas, 2004-2017.

\begin{tabular}{|c|c|c|c|c|c|}
\hline Site & Visits & Banded & Recaptured & $\begin{array}{c}\text { Recaptured } \geq 1 \\
\text { winter later }\end{array}$ & $\begin{array}{c}\text { Recaptured } \geq 3 \\
\text { winters later }\end{array}$ \\
\hline Rural & 194 & 100 & 9 & 7 & 5 \\
\hline Grand total & 236 & 201 & 36 & 28 & 8 \\
\hline
\end{tabular}


We thank the managers of Las Palomas Wildlife Management Area, Quinta Mazatlan, and Valley Nature Center for access, and also subpermittee C. C. Brush and the many volunteers who assisted with bird-banding over the years.

\section{Literature Cited}

Arvin, J. C. 2005. Birds of the South Texas brushlands, a field checklist. Texas Parks and Wildlife Department, Austin.

BRush, T. 2005. Nesting birds of a tropical frontier, the Lower Rio Grande Valley of Texas. Texas A\&M University Press, College Station.

Gilbert, W. M., M. K. Sogge, And C. Van Riper III. 2010. Orangecrowned warbler (Oreothlypis celata), version 2.0. In The Birds of North America (A. F. Poole, editor). Cornell Lab of Ornithology, Ithaca, New York. doi:10.2173/bna.101.

Lockwood, M. L., and B. Freeman. 2014. The TOS handbook of Texas birds. Second edition. Texas A\&M University Press, College Station.
Monroy-Ojeda, A., M. Grosselet, G. Ruiz, and E. Del Valle. 2013. Winter site fidelity and winter residency of six migratory Neotropical species in Mexico. Wilson Journal of Ornithology 125:192-196.

Rosenberg, K. V., R. D. Ohmart, W. C. Hunter, and B. W. Anderson. 1991. Birds of the Lower Colorado River Valley. University of Arizona Press, Tucson.

Ruiz-Gutierrez, V., W. L. Kendall, J. F. Saracco, and G. C. White. 2016. Overwintering strategies of migratory birds: a novel approach for estimating seasonal movement patterns of residents and transients. Journal of Applied Ecology 53:10351045.

Somershoe, S. G., C. D. Brown, and R. T. Poole. 2009. Winter site fidelity and over-winter site persistence of passerines in Florida. Wilson Journal of Ornithology 121:119-125.

Submitted 18 August 2017. Accepted 25 July 2018. Associate Editor was Michael Scott Husak. 